\title{
Amino Acids Composition of Liver, Heart and Kidneys of Thryonomys swingerianus (Temminck 1827) Compared
}

\author{
Emmanuel Ilesanmi Adeyeye ${ }^{1, a^{*}}$, Olajide Ayodele ${ }^{2, b}$ \\ and Joshua Iseoluwa Orege $\mathrm{B}^{3, \mathrm{c}}$ \\ ${ }^{1}$ Department of Chemistry (Analytical Unit), \\ ${ }^{2,3}$ Department of Industrial Chemistry, \\ 1,2,3Ekiti State University, PMB 5363, Ado- Ekiti, Nigeria \\ aE-mail: eiadeyeye@yahoo.com, adeyeyeilesanmi2012@gmail.com \\ bE-mail: olajide.ayodele@eksu.edu.ng 'E-mail: joshua.orege@eksu.edu.ng
}

${ }^{*}$ Corresponding author

Keywords: Grasscutter; red viscera; amino acids

Abstract: Amino acids composition of Thryonomys swingerianus is reported. Whereas protein values $\left(\mathrm{g} 100 \mathrm{~g}^{-1}\right)$ had liver (74.1), kidney (91.5), heart (84.6); corresponding total amino acid values were 93.5, 83.2 and 80.6. True protein from the crude protein of the samples ran thus: liver $>$ kidney $>$ heart. Of the twenty parameters reported on, liver was best in 12/20 (60.0\%), kidney and heart both shared the second position of 4/20(20\%) each. Among the essential amino acids, leucine predominated in both liver $\left(7.96 \mathrm{~g} 100 \mathrm{~g}^{-1}\right.$ protein) and kidney $\left(8.11 \mathrm{~g} 100 \mathrm{~g}^{-1}\right.$ protein) but valine $\left(6.21 \mathrm{~g}^{100 \mathrm{~g}^{-1}}\right.$ protein) predominated in the heart. The P-PER values were; P-PER 12.78 (liver), 2.91(kidney), 0.716 (heart) and P-PER $2: 2.71$ (liver), 2.90 (kidney), 0.564 (heart). However, there was a reverse between liver and kidney in the EAAI values with liver (92.0) > kidney $(90.2)>$ heart (87.6) with corresponding $\mathrm{BV}$ values of $88.5>86.6>83.7$. In the amino acids scoring pattern, Ser was limiting in liver $(0.533)$ and heart (0.394) but Thr (0.490) in kidney in whole hen's egg score comparison; in FAO/WHO scoring standards, Thr was limiting in liver (0.988) and kidney (0.625) but Leu (0.459) in heart. In pre-school requirements, liver recorded no limiting amino acid whereas Thr was limiting in kidney (0.735) and Leu was limiting in the heart (0.486). T. swingerianus red viscera was compared with the red viscera of livestock animals (cattle, sheep and pork) as well as FAO/WHO/UNU standards for total essential amino acids. Our results when compared with the livestock red viscera (without Trp) and $\mathrm{FAO} / \mathrm{WHO} / \mathrm{UNU}$ (g100g ${ }^{-1}$ protein), we have heart: grasscutter/cattle/sheep/pig: 45.3 /46.0/42.7/46.6; kidney: grasscutter/cattle/sheep/pig: 47.6/43.8/42.5/46.7; liver: grasscutter/cattle/ sheep/pig: 50.7/47.7/41.5/47.5 and grasscutter liver/kidney/heart/ FAO/WHO/UNU: 50.7/47.6/45.3/32.8 showing that all the red viscera values in $T$. swingerianus were better than the essential amino acids in the FAO/WHO/UNU standards and livestock red viscera. Statistical values showed that significant differences existed among the samples at $\mathrm{r}=0.01$.

\section{Amino Acids to be Encountered in this Report}

Lysine (C6H14N2O2-PubChem,CID 5962], leucine [C6H13NO2-PubChem,CID 6106]; glutamic acid [C5H9NO4-PubChem,CID 33032]; methionine [C5H11NO2S-PubChem,CID 6137); alanine (C3H7NO2-PubChem, CID 5950]; aspartic acid [C4H7NO4-PubChem,CID 5960]; nor leucine [C6H13NO2-PubChem, CID 21236]; arginine [C6H14N4O2-PubChem,CID 6322]; cystine [C6H12N2O4S2-PubChem,CID 67678],valine [C4H11NO2-PubChem, CID 6287]; threonine [C4H9NO3-Pubchem,CID 6288]; tryptophan [C11H12N2O2-PubChem, CID 6305]; isoleucine[C6H13NO2-PubChem,CID 791]; phenylalanine [C9H11NO2-PubChem,CID 6925665]; histidine [C6H9N3O2-PubChem,CID 6274]; tyrosine [C9H11NO3-PubChem,CID 6057]; serine [C3H7NO3-PubChem,CID 5951]. 


\section{PubChem}

PubChem is a database of chemical molecules and their activities against biological assays. Each compound in PubChem is identified by a unique system Compound Identifier (CID) accession number. The system is maintained by the National Center for Biotechnology Information (NCBI), a component of the National Library of Medicine, which is part of United States National Institute of Health (NIH). PubChem contains substance descriptions and small molecules with fewer than 1000 atoms and 1000 bonds [1]. Precisely, CID is Compound Identification Number [2].

\section{Introduction}

Grasslands are sources of food, forage and energy as well as providing a natural habitat for a variety of wildlife that provide a bulk of the food resources for 800 million of the world's population [3]. According to Stypinski [4], grasslands provide forage for grazing and browsing animals, both domestic and wild; African grasslands wildlife include the giant rodent called the grasscutter (by West Anglophone Africa), hedgehog (Central Africa), agouti (in French-speaking West Africa), greater cane rat (Eastern and Southern Africa).

The grasscutter, Thryonomys swinderianus Temminck 1827 is a large rodent found in Africa $[4,5,6]$. As a rodent, the grasscutter is surpassed in size only by the purcupine Hystrix africaeautralis and Hystrix cristata [6]. The taxonomic details of the animal have been given as follows. Classification: Biota $>$ Animalia $($ Kingdom) $>$ Chordata $($ Phylum) $>$ Vertebrata (Subphyllum) $>$ Mammalia (Class) $>$ Rodentia (Order) $>$ Thryonomyidae (Thryonomys) (Family) Fitzinger, $1867>$ Genus (Thryonomys) $>$ Species (Thryonomys swinderianus Temmick 1827) [7].

Wildlife has been an important protein source for many West African countries over centuries [8]. Rodents are known to be the most preferred and commonly consumed bush animals and remain as the main source of protein for developing countries $[9,10]$. Rural dwellers depend mostly on bush meat as an economic and protein source for livelihood [11]. Ghana and Nigeria are well-known for their consumption of bush meat. Bush meat is popular and important in many traditional festivities among African communities [12] and among the wild animals is the grasscutter [5]. Grasscutter farming is common nowadays and it is farmed as a micro-livestock species in many African countries [13]. In Southern Nigeria, grasscutter is one of the most sold and consumed bushmeat [14] since we have no religious prohibitions for the consumption of grasscutter $[15,16]$. Crude protein content of grasscutter is about $22.7 \%$ compared with $20.7 \%$ for rabbit, $19.25 \%$ for chicken and $18.2 \%$ for beef with less fat and cholesterol than beef, mutton and pork [17]. Adeyeye et al. [18] reported on the lipid profile of the skin, muscle and liver of grasscutter and found that all of them contained good PUFA, showed PUFA/SFA value was higher than the minimum recommended value of 0.45 ; with values of 0.86 (skin), 1.26 (muscle) and 1.07 (liver). Also, Adeyeye and Jegede [19] noted that high levels of both essential and non-essential amino acids are in the meat of grasscutter. In many developing countries meat animals are frequently slaughtered only for the carcass, whereas a number of byproducts, which can be obtained quite easily, could help to improve the supply of low cost, high protein foods for people [20]. Meat animals yield, apart from their carcasses, a considerable amount of parts which are biologically and hygienically fit for human consumption. They are generally consumed either as main ingredients in traditional dishes or as ingredients in meat products. Heart, kidney and liver are all consumed as direct meat products. The so-called red viscera: liver, heart, kidneys, tongue and neck sweetbread (thymus) are normally obtained and marketed as "fancy meats" [20].

Heart is an organ which is in almost all instances an edible part of an animal. Among the various sorts of offal, it is unusual in that it consists almost entirely of muscle. Hearts of older animals are most likely to be tough and to need marinating before being cooked [21]. Liver is a relatively large organ in most animals, birds and fish, usually edible and in some cases delicious. Livers are appreciated in most parts of the world although consumption is low in North America. Livers lend themselves well to the making of pastes, stuffing, sausages and the like. Among the other ingredients which go well with animal livers are bacon, outmeal, sour cream, sharp apples, onions, shallots, 
garlic, marjoram and sage [21]. Kidney is rich in nutrients and proteins. Kidney meat contains omega 3 fatty acids. It is also known to contain anti-inflammatory properties and to be good for the heart. Further, a number of benefits have been ascribed to kidney beans.

It is well known that a person's health, physical development and work capacity depend on the fulfilment of protein requirements both in quantity and in quality. Protein quality is evaluated from the content of essential amino acids, the relative proportions in which they are present and the extent to which the protein is digested [20]. This study wants to report on the amino acids composition of three fancy meats (liver, heart, kidney) and to find out if any significant difference exists in the amino acid compositions of the three red viscera organs of Thryonomys swinderianus.

\section{Materials and Methods}

Collection of samples: Local hunters were commissioned for the supply of grasscutter caught in the wild from Iworoko Ekiti, Nigeria. The animals (five of them) were authenticated in the Department of Wildlife, Fisheries and Environment, Ekiti State University, Ado Ekiti, Nigeria.

Sample treatment: The method used in processing the grasscutter meat was by scalding. Scalding involved dipping the animal in hot water to ease the removal of the fur [8]. The animal fur was removed and the animal dissected. The three fancy meats were carefully removed, washed in distilled water and oven dried to constant weight. This was dry milled into flour, kept in the laboratory refrigerator at $37^{0} \mathrm{~F}\left(2.8^{0} \mathrm{C}\right)$, pending analyses.

\section{Determination of amino acids}

Defatting: Weights taken ranged from $0.1366-0.1688 \mathrm{~g}$ of the samples into extraction thimble, fat extracted with chloroform/methanol mixture using a Soxhlet extraction apparatus [22]. The extraction lasted 5-6 h.

Hydrolysis of the samples: Between 30 to $35 \mathrm{mg}$ of the defatted samples were weighed into glass ampoules. Seven millilitres of $6 \mathrm{M} \mathrm{HCl}$ were added and oxygen was expelled by passing nitrogen gas into the ampoule (to avoid possible oxidation of some amino acids during hydrolysis). Each glass ampoule was then sealed with a Bunsen flame and put into an oven at $105^{\circ} \mathrm{C} \pm 5^{\circ} \mathrm{C}$ for $22 \mathrm{~h}$.

The ampoule was then allowed to cool before breaking open at the tip and the content was filtered to remove the humins.

The filtrate was then evaporated to dryness at $40^{\circ} \mathrm{C}$ under vacuum in a rotary evaporator. Each residue was then dissolved with $5 \mathrm{ml}$ of acetate buffer and stored in a plastic specimen bottle and kept in the deep freezer.

Sample analysis: The method of analysis was by ion exchange chromatography (IEC) [23]. The amount loaded for each sample was $5-10 \mu 1$ each. These were dispensed into the cartridge of the analyzer. The Technicon Sequential Multisample Amino Acid Analyzer (TSM) (Technicon Instruments Corporation, New York) was used for the analysis. The TSM analyzer was designed to separate and analyse free acidic, neutral and basic acids of the hydrolysate. The period of an analysis lasted for $76 \mathrm{~min}$ for each sample. The column flow rate was $0.50 \mathrm{~mL} / \mathrm{min}$ at $60^{\circ} \mathrm{C}$ with reproducibility consistent within $\pm 3 \%$. The net height of each peak produced by the chart record of the TSM (each representing an amino acid) was measured and calculated. The values reported were averages of two determinations. Tryptophan was not determined due to cost. The nitrogen was estimated by the micro-Kjeldahl method [24] with crude protein taken as $\mathrm{N} \mathrm{x} \mathrm{6.25.} \mathrm{Norleucine}$ (PubChem, CID 21236) which is an unnatural amino acid is usually used experimentally to study protein structure and function. It was used as the internal standard in the analyses for the amino acids composition.

Some calculations were made from the analytical results:

i. Estimation of isoelectric point $(p I)$ : The estimation of the isoelectric point $(p I)$ for a mixture of amino acids could be carried out using the equation of the form [25]: 


$$
I P_{m}=\sum_{i=1}^{n} I P_{i} X_{i}
$$

where $\mathrm{IP}_{\mathrm{m}}$ was the isoelectric point of the mixture of amino acids, $\mathrm{IP}_{\mathrm{i}}$ was the isoelectric point of the $\mathrm{i}^{\text {th }}$ amino acid in the mixture and Xi was the mass or mole fraction of the $\mathrm{i}^{\text {th }}$ amino acid in the mixture.

Estimation of predicted protein efficiency ratio (P-PER): Computation of protein efficiency ratio (C- PER or P-PER) was done using the equations suggested by Alsmeyer et al. [26].

$$
\begin{aligned}
& \text { P-PER }_{1}=-0.468+0.454(\text { Leu })-0.105(\text { Tyr }) \\
& \text { P-PER }_{2}=-0.684+0.456 \text { (Leu) }-0.047 \text { (Pro) }
\end{aligned}
$$

ii. Leucine/isoleucine ratio: The leucine/isoleucine ratios, their differences and their percentage differences were calculated.

iii. Estimation of essential amino acid index (EAAI): The method of EAAI calculation due to Oser [27] using the egg protein amino acid as the standard.

iv. Estimation of biological value (BV): Computation of biological value (BV) was calculated following the equation of Oser [27]:

$$
\text { Biological value }=1.09(\text { EAAI })-11.73
$$

v. Computation of amino acid scores: The amino acid scores were computed using three different methods:

$>\quad$ Scores based on amino acid values compared with whole hen's egg amino acid profile [28].

$>\quad$ Scores based on essential amino acid scoring pattern [29].

$>\quad$ Scores based on essential amino acid suggested pattern of requirements for preschool children [30].

\section{Statistical evaluation}

Data results from relevant Tables were subjected to statistical analysis of correlation coefficient $\left(\mathrm{r}_{\mathrm{xy}}\right)$, coefficient of determination $\left(\mathrm{r}_{\mathrm{xy}}{ }^{2}\right)$, regression $\left(\mathrm{R}_{\mathrm{xy}}\right)$, coefficient of alienation $\left(\mathrm{C}_{\mathrm{A}}\right)$ and index of forecasting efficiency (IFE). Other calculations made were the grand mean, standard deviation (SD) and coefficient of variation $(\mathrm{CV} \%)$. The $\mathrm{r}_{\mathrm{xy}}$ was converted to the critical table value to see if significant differences existed among the three fancy meats amino acid results at $\mathrm{r}_{=0.01}$ [31].

\section{Results}

In Table 1 we have the amino acid profiles for the three samples. On parameter basis, the values variation was low since the coefficient of variation $(\mathrm{CV} \%)$ ranged between 2.58 and 43.4. The most varied amino acid was Leu whose values ranged between $3.21-8.11 \mathrm{~g}_{100 \mathrm{~g}^{-1}}$ and the least varied was

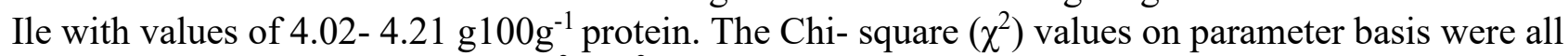
not significant at $\alpha=0.05$ since all $\chi_{\mathrm{c}}^{2}<\chi^{2}$ T. Among the amino acids, the most concentrated value was observed in Glu with values of $12.0-13.1 \mathrm{~g}^{100 \mathrm{~g}^{-1}}$, mean (12.7) and CV\% (4.58); it is an acidic amino acid. The least concentrated amino acid was Cys ranging from $1.502 .20 \mathrm{~g} 100 \mathrm{~g}^{-1}$, mean (1.95) and CV\% (20.0). Among the essential amino acids, Leu was the most concentrated and closely followed by Lys with values of 5.61- $6.66 \mathrm{~g} 100 \mathrm{~g}^{-1}$ protein, \pm 6.26 and $\mathrm{CV} \%(9.04)$; least essential amino acid was Thr with values of $2.50-3.95 \mathrm{gl} 00 \mathrm{~g}^{-1}$, mean $(2.98)$ and $\mathrm{CV} \%$ (28.1). Whereas the highest total

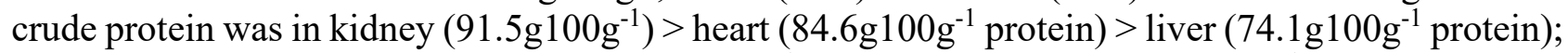

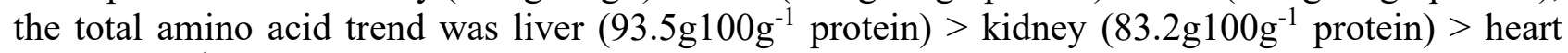
$\left(80.6 \mathrm{~g}_{100 \mathrm{~g}^{-1}}\right.$ protein). This showed that liver moved from the third position (crude protein, $\left.74.1 \mathrm{~g} 100 \mathrm{~g}^{-1}\right)$ to first position in the amino acid profile $\left(93.5 \mathrm{~g} 100 \mathrm{~g}^{-1}\right)$; kidney was in the first position

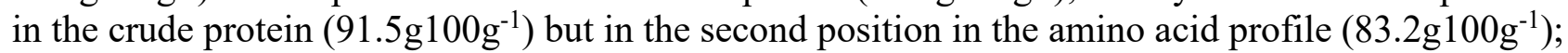
the heart was in the second position in crude protein $\left(84.6 \mathrm{~g}_{\left.100 \mathrm{~g}^{-1}\right)}\right)$ but in the third position in the amino acid profile $\left(80.6 \mathrm{~g}_{100 \mathrm{~g}^{-1}}\right)$. The amino acid composition showed that the true protein trend in the samples was liver $>$ kidney $>$ heart. 
Table 2 depicted the results of the statistical analysis of the data in Table 1. The pairwise comparisons were liver/kidney, kidney/heart and liver/heart. The statistical parameter investigated were correlation coefficient $\left(r_{x y}\right)$, variance $\left(r_{x y}{ }^{2}\right)$, regression coefficient $\left(R_{x y}\right)$, coefficient of alientation $\left(\mathrm{C}_{\mathrm{A}}\right)$ and index of forecasting efficiency (IFE). The calculated $r_{x y}$ was subjected to $r_{x y}$ Table at critical level of $r_{=0.01}$. All the $r_{x y}$ values were high $(0.9956-0.9977)$ and significant since $r_{c}(0.9956-0.9977)>$

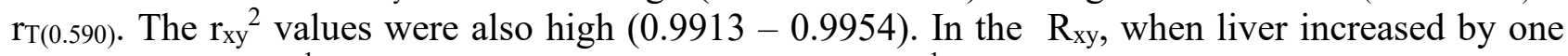
unit of $1.00 \mathrm{~g}_{100 \mathrm{~g}^{-1}}$, kidney would increase by $1.25 \mathrm{~g} 100 \mathrm{~g}^{-1}$ for liver $/ \mathrm{kidney}$; in kidney/heart, when kidney increased by $1.00 \mathrm{~g} 100 \mathrm{~g}^{-1}$, the heart increased by $0.9188 \mathrm{~g} 100 \mathrm{~g}^{-1}$; in liver/heart, when

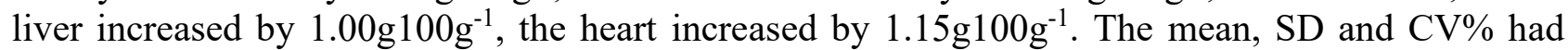
these trends: liver $(9.71 \pm 16.4, \quad \mathrm{CV} \%=176)$, kidney $(9.31 \pm 20.6, \quad \mathrm{CV} \%=212)$ and heart $(9.18 \pm 19.0, \mathrm{CV} \%=207)$. The highest mean concentration was the kidney but it was also having the most varied results 9.71 (mean) 20.6 (SD) and 212 (CV\%). The mean value in liver $\left(9.31 \mathrm{~g} 100 \mathrm{~g}^{-1}\right)$

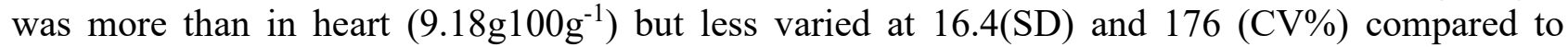
19.0 (SD) and $207(\mathrm{CV} \%)$ in the heart. The $\mathrm{C}_{\mathrm{A}}$ values were all low at liver/kidney (0.0679), kidney/heart (0.0728) and liver/heart (0.0934) showing a progressive increase as shown.

On the other hand, the IFE values were all high but progressively decreased in reverse to what was observed in $\mathrm{C}_{\mathrm{A}}$ : liver/kidney (0.9321), kidney/heart (0.9272) and liver/heart (0.9066). The $\mathrm{C}_{\mathrm{A}}$ worked in reverse order as IFE; that is; the greater the $\mathrm{C}_{\mathrm{A}}$, the lower the IFE and vice versa. However, $\mathrm{C}_{\mathrm{A}}+\mathrm{IFE}=1.00$ or $\mathrm{C}_{\mathrm{A}}+\mathrm{IFE}=100$. Whereas $\mathrm{C}_{\mathrm{A}}$ meant the error of prediction of relationship between two compared entities (like liver/heart), IFE on the other hand meant a value of reduction in the error of prediction of relationship between the two entities. Thus, when IFE $>\mathrm{C}_{\mathrm{A}}$, prediction of relationship is easy but when $\mathrm{C}_{\mathrm{A}}>\mathrm{IFE}$, then error of prediction is high and prediction of relationship is difficult. From Table 2 all IFE values $>$ all $\mathrm{C}_{\mathrm{A}}$ values and hence prediction of relationship was high. Therefore, the bio-chemical activities can be carried out interchangeably in liver/kidney, kidney/heart and liver/heart.

These concentrations of essential, aromatic, non-essential, neutral, etc. amino acid ( $\mathrm{g} 100 \mathrm{~g}^{-1}$ protein) of grasscutter had all been depicted in Table 3. The total non-essential amino acid (TNEAA) ranged as $48.4 \mathrm{~g}_{100 \mathrm{~g}^{-1}}(51.8 \%)$ liver, $40.0 \mathrm{~g} 100 \mathrm{~g}^{-1}(48.0 \%)$ kidney and $40.0 \mathrm{~g}_{100 \mathrm{~g}^{-1}}(49.7 \%)$ heart. In the total essential amino acid (TEAA), we have liver $\left(45.1 \mathrm{~g} 100 \mathrm{~g}^{-1}, 48.2 \%\right)$, kidney $\left(43.2 \mathrm{~g} 100 \mathrm{~g}^{-1}\right.$,

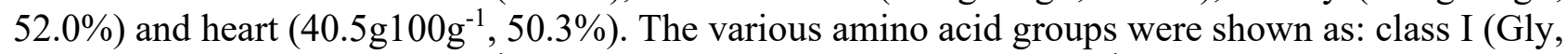
Val, Leu, Ile; 23.9-29.9g100g-1); class II (Ser, Thr; 5.61- 8.16g100g-1); class III (Met, Cys; 4.16-

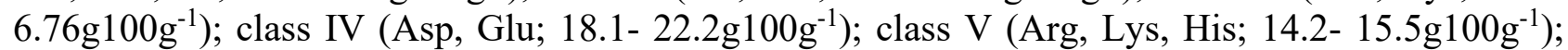

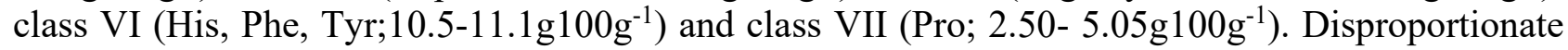
values of \% Cys in TSAA could be noticed in Table 3 as follows: liver (51.7), kidney (28.3) and heart (32.5). The Leu/Ile ratio values were low at 0.762- 2.02. Both P-PER 1 and 2 were high in liver (2.78 versus 2.71$)$ and kidney (2.91 versus 2.90$)$ but both were low in heart $(0.716$ versus 0.564$)$. The EAAI values were all high at 87.6-92.0 with corresponding high values of BV of 83.7- 88.5. All the $p I$ values were within the acidic range with values of 4.80- 5.51.

The amino acid scores in comparison with whole hen's egg amino acid profile have been shown in Table 4. All the $\chi^{2}$ values were low and not significant at $\alpha=0.05$. Also, the CV\% were low at 2.58 - 38.0. The scores in Gly, Glu and Phe were each either 1.00 or $>1.00$. Other amino acids with scores $>1.00$ were Pro (liver, heart); Lys (liver, kidney); Arg (liver, heart) and Cys (liver, heart). The limiting amino acid varied between Ser and Thr. In Ser, it was 0.533 (liver) and 0.394 (heart) whereas Thr (0.490) was limiting in kidney.

Data in Table 4 was statistically analyzed as shown in Table 5. All the three $r_{x y}$ were high and significant at levels of $0.7818-0.8413$; although values were lower than in Table 2 . The $\mathrm{r}_{\mathrm{xy}}{ }^{2}$ values were also high $(0.6113-0.8413)$ but lower than in Table 2 . The range of $\mathrm{R}_{\mathrm{xy}}$ was $0.5565-1.04$, again lower than in Table 2. The CV\% values were low at $37.0-45.2$. The $\mathrm{C}_{\mathrm{A}}$ values were much higher than in Table 2 with values of $0.5406-0.6235$ with much lower IFE (compared with Table 2) values at $0.3765-0.4594$. That is, $\mathrm{C}_{\mathrm{A}}>$ IFE, hence, prediction of relationship between paired samples would be difficult since the reduction in the error of prediction was low. 
In Table 6 we have the score comparison between our amino acids results and the FAO/WHO [29] standards. Whereas Thr was limiting in liver (0.988) and kidney (0.625), Leu (0.459) was limiting in the heart. All the $\chi^{2}$ values were not significantly different at $\alpha=0.05$. Also, all the CV\% values were low and ranged from $2.31-28.1$. In the liver, only $\mathrm{Thr}$ had its score $<1.0$; in the kidney, both Val and Thr had their scores $<1.0$ and in the heart, Thr and Leu had their score values $<1.0$.

The data from Table 6 were statistically analyzed and the results were shown in Table 7 . The $r_{x y}$ values were low $(0.4705-0.6576)$ and not significant at $r=0.01$. The mean, SD and CV\% were low. The $\mathrm{C}_{\mathrm{A}}$ values were high with corresponding low values of IFE having values of $11.76 \%$ 24. $66 \%$.

The pre- school essential amino acid scores were shown in Table 8. No limiting amino acid values were observed in the liver; all values were $>1.00$. In the kidney only Thr had $<1.00$ score hence it was the limiting amino acid in the kidney. In the heart, Thr (0.735), Leu (0.486) and Lys $(0.967)$ had scores $<1.00$ each but Leu was the limiting amino acid. All $\chi^{2}$ values were not significant. The CV\% values ranged from 2.42 - 43.5. It is interesting to note that Leu had CV\% of 43.4 in Table 6 (FAO/WHO comparison) and Leu also recorded CV\% of 43.5 in Table 8 (pre- school child requirements comparison).

In Table 9, data from Table 8 were statistically analyzed. The $r_{x y}$ value for liver/kidney was low (0.6269) and insignificant at $r=0.01$. On the other hand, $r_{x y}$ values for kidney/heart $(0.8621)$ and liver/heart $(0.8072)$ were both high and significant at $r=0.01$. The $r_{x y}{ }^{2}$ values were low to high at $0.3930-0.7431$. $\mathrm{R}_{\mathrm{xy}}$ was much better than the values in Table 7 with values of $0.9627-2.21$. Values of mean, $\mathrm{SD}$ and $\mathrm{CV} \%$ were all generally low. $\mathrm{C}_{\mathrm{A}}$ was high $(0.4391-0.7791)$ whereas IFE was low $(0.2209-0.5609)$.

Figure 1 contained the summary of the amino acids profiles into Factors A and B. The importance of this was to see if values in column for factor A means would be similar to Factor B means.

Figure 2 depicted the red viscera of grasscutter compared to the livestock animals (cattle, sheep and pig) viscera and the $\mathrm{FAO} / \mathrm{WHO} / \mathrm{UNU}[30]$ standard.

\section{Discussion}

The overall amino acid profiles in Table 1 showed varied distributions of each type of amino acids in each sample. These parameters were generally high in the samples: Lys, His, Arg, Pro, Gly, Cys, Val, Met, Ile, Leu, protein and total amino acids. The trend of concentration for high levels of amino acids in liver was: Glu $>$ Asp $>$ Gly $>$ Lys $=$ Arg $>$ Val $>$ Phe $>$ Pro; in kidney concentration ran thus: Glu $>$ Leu $>$ Asp $>$ Lys $>$ Arg $>$ Gly $>$ Phe; in heart we have: Glu $>$ Gly $>$ Val $>$ Asp $>$ Lys $>$ Phe. Hence while liver had nine parameters having values greater than $5.00 \mathrm{~g}_{100 \mathrm{~g}^{-1}}$ protein, kidney had seven and heart had six. Whereas liver had four EAA in its first topmost nine parameters, both kidney and heart had three each. The values observed for the crude protein and total amino acids were of major interest. Liver provided the lowest protein value $\left(74.1 \mathrm{~g} 100 \mathrm{~g}^{-1}\right)$ but recorded the highest value of total amino acid $\left(93.5 \mathrm{~g}_{100 \mathrm{~g}^{-1}}\right.$ protein). The most probable reason must be that the liver had more true protein than both other samples. So, the run for the true protein in the samples would be

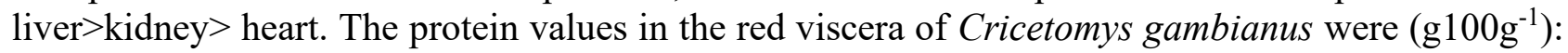
heart (74.8), kidney (85.8) and liver (83.9) [32]; these values were also highly comparable with the present results. In the organs of guinea - fowl, the protein values $\left(\mathrm{g}_{100 \mathrm{~g}^{-1}}\right)$ were: liver (73.6) and heart (74.9) [33]. The amino acid profiles of the present report compared very favourably with the amino acid profiles of the heart and liver of Cricetomys gambianus [34]. However, the amino acid values in African giant pouch rat liver was $86.9 \mathrm{~g} 100 \mathrm{~g}^{-1}$ and $86.3 \mathrm{~g} 100 \mathrm{~g}^{-1}$ (heart) [34].

The class and group divisions of the amino acids were depicted in Table 3. Class I group were amino acids with aliphatic side chains (hydrogen and carbons) = Gly, Val, Leu, Ile. The percentage values range here ran as 29.7-32.0 with $\mathrm{CV} \%$ of 4.58 . Class II were amino acids with side chains containing hydroxylic $(\mathrm{OH})$ groups $=$ Ser, Thr having total percentage values of $6.96-8.73$ and CV\% (11.3). Class III were the (TSAA) of Met and Cys, these were amino acids with side chains containing sulphur atoms. Their percentage range was $4.45-8.43, \mathrm{CV} \%(31.0)$. Class IV were amino acids with 
side chains containing acidic groups or their amides $=$ Asp, Glu. The percentage range was 22.4 24.5, CV\% (4.43). Amino acids with side chains containing basic groups = Arg, Lys, His were in Class V. Their percentage range was 16.6 - 18.0. Class VI were amino acids containing aromatic rings $=$ His, Phe, Tyr, Trp with percentage values range of $11.9-13.2$, CV\% (5.19). Total cyclic amino acid was in class VII with percentage range of $3.00-5.71$ and CV\% (31.6). The trend of the mean and $\mathrm{CV} \%$ values of the classes (groups) ran as follows: Class I $(26.1,12.7)>$ class IV $(20.2$, $10.1)>$ class $V(14.9,4.33)>$ class VI $(10.7,3.13)>\operatorname{class}$ II $(6.76,19.1)>\operatorname{class}$ III $(5.41,24.1)>$ class VII $(4.05,33.6)$.

The TSAA of the samples ranged between $4.16-6.76 \mathrm{~g} 100 \mathrm{~g}^{-1}$ which were highly comparable or even higher to the value of $58 \mathrm{mgg}^{-1}$ protein recommended for infants [30]. The aromatic amino acid range suggested for ideal protein $\left(68-118 \mathrm{mgg}^{-1}\right.$ protein) [30] was highly comparable with present report with values in the total essential aromatic amino acid $\left(10.5-11.1 \mathrm{~g} 100 \mathrm{~g}^{-1}\right.$ protein). The present values were almost equivalent to the ideal protein and hence could very well serve as a food supplement to low protein food sources. Values of the EAA were $40.5-45.1 \mathrm{~g} / 100 \mathrm{~g}$ with percentage values of $48.2-52.0$. These values were above the $39 \%$ considered adequate for ideal protein food for infants, $26 \%$ for children and $11 \%$ for adults [30]. The EAA/TAA in egg is 50\% [35].

In the predicted protein efficiency ratios, we had these values: P-PER $1(0.716-2.91)$ and $\mathrm{P}-\mathrm{PER}_{2}$ $(0.564-2.90)$. The in vivo P- PER is of the order of 2.2 [36]. In Cricetomys gambianus, the P-PER for liver was 2.62 and the one for heart was 2.32 [34]. From these results, it was obvious that the heart will be the least physiologically utilized protein among the samples. Among the various sorts of offal, the heart is unusual in that it consists almost entirely of muscle. Moreover, the nature of the organ is such that the muscles are in constant use, pumping blood around the body, while the animal is alive; and hearts of older animals are therefore likely to be tough and to need marinating before being cooked [21].

It is well known that a person's health, physical development and work capacity depend on the fulfilment of protein requirements both in quantity and in quality. Protein quality is evaluated from the content of essential amino acids, the relative proportions in which they are present and the extent to which the protein is digested [20]. In general, it has been found that the better the protein, the lower the level in the diet required to produce the highest protein efficiency ratio. This is a clear reflection of the importance of the proper nutritive balance of the amino acids to produce optimum metabolic efficiency. The essential amino acid index (EAAI) of 87.6 - 92.0 and their corresponding biological values (BV) of 83.7 - 88.5 depicted the high quality of the protein of the samples. From literature, we have the following EAAI and BV values for comparison [27]: milk, cow (whole, non-fat, evaporated or dry), EAAI (88) and BV (84, predicted; 90, observed); human, EAAI (87) and BV (83); eggs, chicken (whole, raw or dried), EAAI (100), BV (97, predicted; 96, observed); whites (raw or dried), EAAI (95), BV (92, predicted; 93, observed); yolks (raw or dried), EAAI (93), BV (89, predicted); shellfish (shrimp, including prawns, raw or canned), EAAI (67), BV(61, predicted); Neopetrolisthes maculatus (another shellfish), EAAI (86.9 - 89.9) and BV (83.0 - 86.3) [37]. Using another method of EAAI determination [38] in Cricetomys gambianus, we have values of EAAI 1.31 (liver) and 1.20 (heart) [34]. These literature values show the quality position of the three fancy meats. EAAI is useful as a rapid tool in the evaluation of food formulation for protein quality.

Further to evaluate the protein quality of the fancy meats, Leu/Ile values were calculated getting ratio values of $0.762-2.02$. The most ideal Leu/Ile value is 2.36 [23]. It had been suggested that an amino acid imbalance from excess Leu might be a factor in the development of pellagra [39]. A high Leu imbalance in the diet impairs the metabolism of Trp and niacin, and is responsible for the niacin deficiency in sorghum eaters [40]. Experiments in dogs showed that animals fed sorghum proteins with less than $11 \mathrm{~g} 100 \mathrm{~g}^{-1}$ protein Leu did not suffer from nicotinic acid deficiency [41]. The present Leu values were $3.21-8.11 \mathrm{~g} 100 \mathrm{~g}^{-1}$ protein, they were therefore considered safe and could be beneficially exploited to prevent pellagra in endemic areas [42]. The values of Leu/Ile ratio of 0.762 -2.02 showed that we might not experience concentration antagonism in the samples when consumed as protein source in food. The percentage Cys /TSAA values were 28.3 - 51.7. The (Cys/TSAA) $\%$ in kidney (28.3) and heart (32.5) depicted the usual protein observation for animals shown as follows 
[43]: 27.3 - 32.8\% in Sudananautes africanus africanus; 36.3\% in Macrotermes bellicosus; $25.6 \%$ in Zonocerus variegatus; 35.5\% in Archachatina marginata; 38.8\% in Archatina archatina and $21.0 \%$ in Limicolaria sp. (the last three being land snails found in Nigeria); in N. maculatus the range was $31.9-33.1 \%$ [37]. However, the value of $51.7 \%$ in the liver showed a behaviour of a plant $\% \mathrm{Cys} / \mathrm{TSAA}$; see these literature examples: $62.9 \%$ in coconut endosperm [44]; its range was $58.9-$ $72.0 \%$ in guinea corn [45]; it was $50.5 \%$ in cashew nut [46]; it was $40.7 \%$ in Triticum durum [47] and $44.4 \%$ in Parkia biglobosa [48]. The percentage Cys in TSAA in the diet of rat, chick and pig is $50 \%$ [23] but the value is unknown in man [30]. The presence of cystine and cysteine in the diet would reduce the needs for Met and since almost all the sulphur in the diet was derived from these three amino acids the sulphur content might sometimes be used as an approximate assessment of the adequacy of protein [49]. The isoelectric point, $p I$, was $4.80-5.51$ showing the samples to be in the acidic medium of the $\mathrm{pH}$ range. The $p I$ calculation from amino acids usually assists in the quick production of certain isolate of organic product without evaluating the protein solubility to get to the $p I$.

In Table 4 where we have the amino acids in comparison with whole hen's egg, Ser was limiting in liver (0.533), Thr in kidney (0.490) and in the heart (0.490). Therefore, in order to fulfill the day's needs for all the amino acids in the three fancy meats, 100/53.3 or 1.88 times as much liver protein, or $100 / 49.0$ or 2.04 times as much kidney protein and heart protein, would have to be eaten when each serve as the sole protein source in the diet. The data in Table 4 were translated statistically as shown in Table 5. All the $r_{x y}$ values were positively high and significant at $r=0.01$. Prediction of relationship was slightly difficult because $\mathrm{C}_{\mathrm{A}}>$ IFE in each compared sample parameters. The $\mathrm{R}_{\mathrm{xy}}$ was only greater than 1.00 in kidney/heart (1.04) but others were lower than $1.00 \mathrm{~g}^{100 \mathrm{~g}^{-1}}$ protein.

In Table 6, we have the amino acid scores as compared with FAO/WHO [29] standards. Thr was limiting in liver (0.988) and in the kidney (0.625) but Leu (0.459) was limiting in the heart. In the hiearachy of limiting amino acids, Lys is the first limiting amino acid, second is Met + Cys, third is Thr and fourth is Trp. However, for the basis of discussion, Leu was reckoned with here. Hence, correction factors for liver would be $100 / 98.9$ or 1.01 ; for kidney correction would be 100/45.9 or 2.18; for Leu correction was $100 / 45.9$ or 2.18. In the statistical result shown in Table 7, all the $r_{x y}$ values were low and none was significant at $r=0.01 ; C_{A}>>I F E$ but two of $R_{x y}$ values were each greater than $1.00 \mathrm{~g} 100 \mathrm{~g}^{-1}$ protein.

The essential amino acid scores comparison with pre- school child (2- 5y) requirements were shown in Table 8 . Liver values were all better than the standard values since scores recorded were between 1.12-1.83. In kidney, Thr was limiting at 0.735 with correction factor of $100 / 73.5$ or 1.36 and Leu (0.486) was limiting in heart and has a correction factor of 100/48.6 or 2.06. Values in Table 9 resulted from the statistical analysis of the values in Table 8. The $r_{x y}$ values were positively low to high with those of kidney/heart and liver/ heart being significantly different among each pair. The highest recorded value of $\mathrm{R}_{\mathrm{xy}}$ was observed in liver/ heart with a value of $2.21 \mathrm{~g} 100 \mathrm{~g}^{-1}$ protein. The $\mathrm{C}_{\mathrm{A}}>\mathrm{IFE}$ in liver/kidney and kidney/heart but the reverse was observed in liver/heart.

The summary of the amino acid profiles into Factors A and B was shown in Figure 1. Factor A means constituted amino acids values of the three samples along the vertical axis; Factor B means constituted the amino acid values along the vertical axis as shown in the figure; both containing the essential and non- essential amino acids. Column under Factor B means showed close values at a close range of $42.80-42.96 \mathrm{~g}_{100 \mathrm{~g}^{-1}}$ protein. On the whole, the mean of Factor A means and factor B

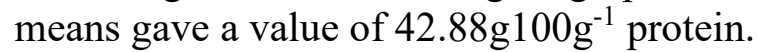

Figure 2 contained information on the comparison of the grasscutter viscera (liver, heart, kidney) with the livestock animal (cattle, sheep, pig) viscera and FAO/WHO/UNU [30] standards. The essential amino acid content of almost all the organs in the grasscutter was very similar to that of viscera from all the three animals and good enough to maintain the nitrogen balance in the organism. 


\section{Conclusions}

Thryonomys swingerianus liver, kidney and heart samples were all good sources of highquality protein of more than average requirements of essential amino acids, high P- PER, high EAAI, high BV but low Leu/Ile ratios. The WHO recommended Val and Ile requirements for school children aged 10 - 12 years of 33 and $30 \mathrm{mg}$ amino acid kg-1 body weight day ${ }^{-1}[29,30]$. For example, a $30 \mathrm{~kg}$ child will require 990 and $900 \mathrm{mg}$ of Val and Ile day ${ }^{-1}$ respectively. From Table 1, 100g of liver protein would provide $4742 \mathrm{mg}$ Val, kidney would provide $4172 \mathrm{mg}$ Val and heart would provide $5254 \mathrm{mg}$ Val to $30 \mathrm{~kg}$ child whereas liver would provide $3112 \mathrm{mg}$ Ile, kidney would provide $3678 \mathrm{mg}$ Ile and heart would provide $3562 \mathrm{mg}$ Ile to $30 \mathrm{~kg}$ child. Whereas the fancy meats would provide more than $4 \mathrm{x}$ (four times) the Ile requirements, the samples would provide more than $3 \mathrm{x}$ (three times) the Val requirements for school children.

\section{Conflict of interest}

Authors declare no conflict of interest

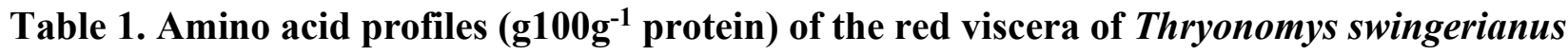

\begin{tabular}{|ll|l|l|l|l|l|l|l|l|}
\hline $\begin{array}{l}\text { Amino } \\
\text { acid }\end{array}$ & CID & Liver & Kidney & Heart & Mean & $\mathrm{SD}^{\#}$ & $\mathrm{CV}^{\dagger}$ & $\chi^{2}$ & Remark \\
\hline Lys* & 5962 & 6.50 & 6.66 & 5.61 & 6.26 & 0.566 & 9.04 & 0.100 & Insignificant \\
\hline His* & 6274 & 2.50 & 2.30 & 2.40 & 2.40 & 0.100 & 4.17 & 0.001 & Insignificant \\
\hline Arg & 6322 & 6.50 & 6.04 & 6.21 & 6.25 & 0.233 & 3.72 & 0.017 & Insignificant \\
\hline Asp & 5960 & 9.05 & 7.50 & 6.06 & 7.54 & 1.50 & 19.8 & 0.593 & Insignificant \\
\hline Thr* & 6288 & 3.95 & 2.50 & 2.50 & 2.98 & 0.887 & 28.1 & 0.470 & Insignificant \\
\hline Ser & 5951 & 4.21 & 4.02 & 3.11 & 3.78 & 0.588 & 15.6 & 0.183 & Insignificant \\
\hline Glu & 33032 & 13.1 & 12.9 & 12.0 & 12.7 & 0.580 & 4.58 & 0.053 & Insignificant \\
\hline Pro & 145742 & 5.05 & 2.50 & 4.60 & 4.05 & 1.36 & 33.6 & 0.915 & Insignificant \\
\hline Gly & 750 & 7.95 & 5.60 & 6.25 & 6.60 & 1.21 & 18.4 & 0.446 & Insignificant \\
\hline Ala & 5950 & 3.40 & 3.05 & 3.21 & 3.22 & 0.175 & 5.44 & 0.019 & Insignificant \\
\hline Cys & 67678 & 2.15 & 1.50 & 2.20 & 1.95 & 0.391 & 20.0 & 0.156 & Insignificant \\
\hline Met* & 6137 & 2.01 & 3.80 & 4.56 & 3.46 & 1.31 & 37.9 & 0.991 & Insignificant \\
\hline Val* & 6287 & 6.40 & 4.56 & 6.21 & 5.72 & 1.01 & 17.7 & 0.358 & Insignificant \\
\hline Ile* & 791 & 4.20 & 4.02 & 4.21 & 4.14 & 0.107 & 2.58 & 0.006 & Insignificant \\
\hline Leu* & 6106 & 7.96 & 8.11 & 3.21 & 6.43 & 2.79 & 43.4 & 2.42 & Insignificant \\
\hline Tyr & 6057 & 3.49 & 2.90 & 2.60 & 3.00 & 0.453 & 15.1 & 0.137 & Insignificant \\
\hline Phe* & 6925665 & 5.10 & 5.25 & 5.60 & 5.32 & 0.257 & 4.83 & 0.025 & Insignificant \\
\hline Nitrogen & 11.9 & 14.6 & 13.5 & 13.3 & 1.41 & 10.5 & 0.296 & Insignificant \\
\hline Protein & & 74.1 & 91.5 & 84.6 & 83.4 & 8.78 & 10.5 & 1.85 & Insignificant \\
\hline Total amino acid & 93.5 & 83.2 & 80.6 & 85.8 & 6.85 & 7.99 & 1.09 & Insignificant \\
\hline
\end{tabular}

*Essential amino acid; ${ }^{\mathrm{S} D}=$ standard deviation; ${ }^{\dagger} \mathrm{CV} \%=$ coefficient of variation; $\chi^{2}=$ Chi-square; for $\chi^{2}, \mathrm{k}-1=3-1=2(\mathrm{df})$, at $\alpha=0.05$. [Note: critical value $=5.99$.]; hence results were insignificantly different; $\mathrm{CID}=$ Compound Identitification Number 
Table 2. Statistical analysis of the data from Table 1 pertaining to amino acid profiles of red viscera of $T$. swingerianus

\begin{tabular}{|l|l|l|l|}
\hline Statistics & Liver/Kidney & Kidney/Heart & Liver/Heart \\
\hline Correlation coefficient $\left(\mathrm{r}_{\mathrm{xy}}\right)$ & 0.9977 & 0.9973 & 0.9956 \\
\hline Variance $\left(\mathrm{r}_{\mathrm{xy}}{ }^{2}\right)$ & 0.9954 & 0.9947 & 0.9913 \\
\hline Regression coefficient $\left(\mathrm{R}_{\mathrm{xy}}\right)$ & 1.25 & 0.9188 & 1.15 \\
\hline Mean $_{1}$ & 9.31 & 9.71 & 9.31 \\
\hline Standard deviation $(\mathrm{SD})_{1}$ & 16.4 & 20.6 & 16.4 \\
\hline Coefficient of variation $(\mathrm{CV} \%)_{1}$ & 176 & 212 & 176 \\
\hline Mean 2 & 9.71 & 9.18 & 9.18 \\
\hline Standard deviation $(\mathrm{SD})_{2}$ & 20.6 & 19.0 & 19.0 \\
\hline Coefficient of Variation $(\mathrm{CV} \%)_{2}$ & 212 & 207 & 207 \\
\hline Coefficient of alienation $\left(\mathrm{C}_{\mathrm{A}}\right)$ & 0.0679 & 0.0728 & 0.0934 \\
\hline Index of forecasting efficiency $(\mathrm{IFE})$ & 0.9321 & 0.9272 & 0.9066 \\
\hline Remark* & Significant diff. & Significant diff. & Significant diff. \\
\hline
\end{tabular}

Mean $_{1} \mathrm{SD}_{1}$ and $\mathrm{CV} \% 1$, all represented the corresponding values in the first member of a pair whereas

$2,2,2$, series corresponded to the second pair of the group; ${ }^{*} r_{x y}$ was significant at $n-2(d f)=n-2=18$ -

$2=16$ at $r=0.01$ with critical value of 0.590

Table 3. Concentrations of essential, aromatic, non-essential, neutral, e.t.c. amino acid $\left(\mathrm{g}^{100 \mathrm{~g}^{-1}}\right.$ protein) of the red viscera of $T$. swingerianus

\begin{tabular}{|l|l|l|l|l|l|l|l|l|}
\hline Amino acid & Class & Group & Liver & Kidney & Heart & Mean & SD & CV\% \\
\hline Total amino acid (TAA) & & & 93.5 & 83.2 & 80.6 & 85.8 & 6.85 & 7.99 \\
\hline $\begin{array}{l}\text { Total non-essential amino acid } \\
\text { (TNEAA) }\end{array}$ & & & 48.4 & 40.0 & 40.0 & 42.8 & 4.85 & 11.3 \\
\hline \% TNEAA & & & 51.8 & 48.0 & 49.7 & 49.9 & 1.88 & 3.78 \\
\hline $\begin{array}{l}\text { Total essential amino acid (TEAA)- } \\
\text { with His }\end{array}$ & & 45.1 & 43.2 & 40.5 & 43.0 & 2.32 & 5.40 \\
\hline $\begin{array}{l}\text { Total essential amino acid (TEAA)- } \\
\text { no His }\end{array}$ & & & 42.6 & 40.9 & 38.1 & 40.6 & 2.28 & 5.62 \\
\hline \%TEAA- with His & & & 48.2 & 52.0 & 50.3 & 50.2 & 1.86 & 3.70 \\
\hline \%TEAA -no His & & & 45.6 & 49.2 & 47.3 & 47.4 & 1.82 & 3.82 \\
\hline $\begin{array}{l}\text { Total aliphatic amino acid (TAIAA) } \\
\text { \% TAIAA }\end{array}$ & Gly, Val, & 29.9 & 24.5 & 23.9 & 26.1 & 3.30 & 12.7 \\
\hline $\begin{array}{l}\text { Total essential aliphatic amino acid } \\
\text { (TEAIAA) }\end{array}$ & & & 32.0 & 29.5 & 29.7 & 30.4 & 1.39 & 4.58 \\
\hline \%TEAIAA & & & 18.6 & 15.9 & 14.4 & 16.3 & 2.09 & 12.8 \\
\hline Total aromatic amino acid (TArAA) & VI & His, Phe, Tyr & 11.1 & 10.5 & 10.6 & 10.7 & 0.335 & 3.13 \\
\hline \%TArAA & & & 11.9 & 12.6 & 13.2 & 12.5 & 0.651 & 5.19 \\
\hline $\begin{array}{l}\text { Total essential aromatic amino acid } \\
\text { (TEArAA) }\end{array}$ & & & 7.60 & 7.55 & 8.00 & 7.72 & 0.247 & 3.19 \\
\hline \% TEArAA & & & 8.13 & 9.07 & 9.93 & 9.04 & 0.900 & 9.96 \\
\hline Total acidic amino acid (TAAA) & IV & Asp, Glu & 22.2 & 20.4 & 18.1 & 20.2 & 2.05 & 10.1 \\
\hline \%TAAA & & & 23.7 & 24.5 & 22.4 & 23.5 & 1.04 & 4.43 \\
\hline Total basic amino acid (TBAA) & V & Arg, Lys, His & 15.5 & 15.0 & 14.2 & 14.9 & 0.645 & 4.33 \\
\hline \%TBAA & & & 16.6 & 18.0 & 17.7 & 17.4 & 0.745 & 4.28 \\
\hline Total neutral amino acid (TNAA) & & & 55.9 & 47.8 & 48.3 & 50.6 & 4.53 & 8.94 \\
\hline \%TNAA & & & 59.7 & 57.5 & 59.9 & 59.0 & 1.37 & 2.32 \\
\hline Total hydroxylic amino acid (THAA) & II & Ser, Thr & 8.16 & 6.52 & 5.61 & 6.76 & 1.29 & 19.1 \\
\hline
\end{tabular}




\begin{tabular}{|c|c|c|c|c|c|c|c|c|}
\hline \%THAA & & & 8.73 & 7.84 & 6.96 & 7.84 & 0.885 & 11.3 \\
\hline Total cyclic amino acid (TCAA) & VII & Pro & 5.05 & 2.50 & 4.60 & 4.05 & 1.36 & 33.6 \\
\hline$\%$ TCAA & & & 5.40 & 3.00 & 5.71 & 4.70 & 1.48 & 31.6 \\
\hline $\begin{array}{l}\text { Total sulphur amino acid (TSAA, } \\
\text { Cys + Met) }\end{array}$ & III & Met, Cys & 4.16 & 5.30 & 6.76 & 5.41 & 1.30 & 24.1 \\
\hline$\%$ TSAA & & & 4.45 & 6.37 & 8.43 & 6.42 & 1.99 & 31.0 \\
\hline$\%$ Cys in TSAA & & & 51.7 & 28.3 & 32.5 & 37.5 & 12.5 & 33.3 \\
\hline Leu/Ile ratio & & & 1.90 & 2.02 & 0.762 & 1.56 & 0.694 & 44.5 \\
\hline |Leu-Ile| difference & & & 3.76 & 4.09 & -1.00 & 2.95 & 1.70 & 57.5 \\
\hline$\% \mid$ Leu-Ile| & & & 4.02 & 4.92 & -1.24 & 3.39 & 1.92 & 56.6 \\
\hline$\% \mid$ Leu-Ile|/Leu & & & 0.505 & 0.607 & -0.386 & 0.499 & 0.110 & 22.1 \\
\hline${\mathrm{P}-\mathrm{PER}_{1} *}^{*}$ & & & 2.78 & 2.91 & 0.716 & 2.14 & 1.23 & 57.6 \\
\hline${\mathrm{P}-\mathrm{PER}_{2} *}^{*}$ & & & 2.71 & 2.90 & 0.564 & 2.06 & 1.30 & 63.1 \\
\hline EAAI $^{\#}$ & & & 92.0 & 90.2 & 87.6 & 89.9 & 2.22 & 2.47 \\
\hline Biological value (BV) & & & 88.5 & 86.6 & 83.7 & 86.3 & 2.42 & 2.80 \\
\hline$P I^{\prime}$ & & & 5.51 & 4.92 & 4.80 & 5.08 & 0.380 & 7.49 \\
\hline
\end{tabular}

*Predicted protein efficiency ratio; ${ }^{\#} \mathrm{EAAI}=$ essential amino acid index; ${ }^{\dagger} p I=$ isoelectric point

Table 4. Amino acid scores of $T$. swingerianus based on whole hen's egg amino acid profile

\begin{tabular}{|l|l|l|l|l|l|l|l|}
\hline $\begin{array}{l}\text { Amino } \\
\text { acid }\end{array}$ & Liver & Kidney & Heart & Mean & SD & CV\% & $x^{2 *}$ \\
\hline Gly & 2.65 & 1.87 & 2.08 & 2.20 & 0.404 & 18.3 & 0.1086 \\
\hline Ala & 0.630 & 0.565 & 0.594 & 0.596 & 0.033 & 5.46 & 0.0031 \\
\hline Ser & 0.533 & 0.509 & 0.394 & 0.479 & 0.074 & 15.5 & 0.0037 \\
\hline Pro & 1.33 & 0.658 & 1.21 & 1.07 & 0.358 & 33.6 & 0.0856 \\
\hline Val & 0.853 & 0.608 & 0.828 & 0.763 & 0.135 & 17.7 & 0.0121 \\
\hline Thr & 0.775 & 0.490 & 0.490 & 0.585 & 0.165 & 28.1 & 0.0181 \\
\hline Ile & 0.750 & 0.718 & 0.752 & 0.740 & 0.019 & 2.58 & 0.0002 \\
\hline Leu & 0.959 & 0.977 & 0.573 & 0.836 & 0.228 & 27.3 & 0.0347 \\
\hline Asp & 0.846 & 0.701 & 0.566 & 0.704 & 0.140 & 19.9 & 0.0131 \\
\hline Lys & 1.05 & 1.07 & 0.905 & 1.01 & 0.090 & 8.93 & 0.0054 \\
\hline Met & 0.628 & 1.19 & 1.43 & 1.08 & 0.412 & 38.0 & 0.1130 \\
\hline Glu & 1.09 & 1.08 & 1.00 & 1.06 & 0.049 & 4.67 & 0.0016 \\
\hline Phe & 1.00 & 1.03 & 1.10 & 1.04 & 0.051 & 4.92 & 0.0018 \\
\hline His & 1.04 & 0.958 & 1.00 & 0.999 & 0.041 & 4.10 & 0.0011 \\
\hline Arg & 1.07 & 0.990 & 1.02 & 1.03 & 0.040 & 3.94 & 0.0011 \\
\hline Tyr & 0.873 & 0.725 & 0.650 & 0.749 & 0.113 & 15.1 & 0.0065 \\
\hline Cys & 1.19 & 0.833 & 1.22 & 1.08 & 0.215 & 19.9 & 0.0309 \\
\hline Total & 0.953 & 0.848 & 0.821 & 0.874 & 0.070 & 7.98 & 0.0032 \\
\hline
\end{tabular}

${ }^{*} \chi^{2}=$ all chi-square values were insignificantly different at $k-1=3-1=2(\mathrm{df})$ at $\alpha=0.05$. [Note: critical value $=5.99$.] 
Table 5. Statistical analysis of the data from Table 4 concerning the amino acid profiles of the red viscera based on whole hen's egg amino acid profiles

\begin{tabular}{|l|l|l|l|}
\hline Statistics & Liver/Kidney & Kidney/Heart & Liver/Heart \\
\hline $\mathrm{r}_{\mathrm{xy}}$ & $0.7818^{*}$ & $0.8413^{*}$ & $0.8032^{*}$ \\
\hline $\mathrm{r}_{\mathrm{xy} 2}$ & 0.6113 & 0.7078 & 0.6451 \\
\hline $\mathrm{R}_{\mathrm{xy}}$ & 0.5565 & 1.04 & 0.7088 \\
\hline $\mathrm{Mean}_{1}$ & 1.01 & 0.879 & 1.01 \\
\hline $\mathrm{SD}_{1}$ & 0.457 & 0.325 & 0.457 \\
\hline $\mathrm{CV} \% 1$ & 45.2 & 37.0 & 45.2 \\
\hline $\mathrm{Mean}_{2}$ & 0.879 & 0.924 & 0.924 \\
\hline $\mathrm{SD}_{2}$ & 0.325 & 0.404 & 0.404 \\
\hline $\mathrm{CV} \% 2$ & 37.0 & 43.7 & 43.7 \\
\hline $\mathrm{C}_{\mathrm{A}}$ & 0.6235 & 0.5406 & 0.5957 \\
\hline $\mathrm{IFE}$ & 0.3765 & 0.4594 & 0.4043 \\
\hline Remark* & Significant diff. & Significant diff. & Significant diff. \\
\hline
\end{tabular}

For Mean $\mathrm{SD}_{1} \mathrm{CV} \% 1$ and the 2, 2, 2 series, see Table 2; $\mathrm{C}_{\mathrm{A}}$ and IFE, see Table 2; * Results significantly different at $\mathrm{r}_{=0.01}, \mathrm{n}-2(\mathrm{df})=\mathrm{n}-2=18-2=16$ at critical level of 0.590

Table 6. Essential amino acid scores of $T$. swingerianus red viscera based on FAO/WHO (1973) [29] standards

\begin{tabular}{|l|l|l|l|l|l|l|l|}
\hline $\begin{array}{l}\text { Amino } \\
\text { acid }\end{array}$ & Liver & Kidney & Heart & Mean & SD & CV\% & $\chi 2^{*}$ \\
\hline Val & 1.28 & 0.912 & 1.24 & 1.14 & 0.202 & 17.6 & 0.0272 \\
\hline Thr & 0.988 & 0.625 & 0.625 & 0.746 & 0.210 & 28.1 & 0.0405 \\
\hline Ile & 1.05 & 1.01 & 1.05 & 1.04 & 0.024 & 2.31 & 0.0207 \\
\hline Leu & 1.14 & 1.16 & $0.459^{\prime}$ & 0.920 & 0.399 & 43.4 & 0.1062 \\
\hline Lys & 1.18 & 1.21 & 1.02 & 1.14 & 0.102 & 8.99 & 0.0070 \\
\hline Met+Cys & 1.19 & 1.51 & 1.93 & 1.54 & 0.371 & 24.0 & 0.0918 \\
\hline Phe+Tyr & 1.43 & 1.36 & 1.37 & 1.39 & 0.038 & 2.73 & 0.0010 \\
\hline Total & 1.01 & 1.12 & 1.05 & 1.06 & 0.056 & 5.25 & 0.0021 \\
\hline
\end{tabular}

$* \chi_{2}=$ all chi-square values were insignificantly different at $\mathrm{k}-1=3-1=2(\mathrm{df})$ at $\alpha=0.05$. [Note: critical value $=5.99$.]

Table 7. Statistical analysis of the data from Table 6 concerning the amino acid profiles of the red viscera of $T$. swingerianus_based on FAO/WHO (1973) [29] scoring standards

\begin{tabular}{|l|l|l|l|}
\hline Statistics & Liver/Kidney & Kidney/Heart & Liver/Heart \\
\hline rxy & 0.5307 & 0.6576 & 0.4705 \\
\hline rxy2 & 0.2817 & 0.4324 & 0.2214 \\
\hline Rxy & 0.9774 & 1.09 & 1.44 \\
\hline Mean $_{1}$ & 1.16 & 1.11 & 1.16 \\
\hline $\mathrm{SD}_{1}$ & 0.1479 & 0.2724 & 0.1479 \\
\hline $\mathrm{CV} \% 1$ & 12.8 & 24.5 & 12.8 \\
\hline $\mathrm{Mean}_{2}$ & 1.11 & 1.09 & 1.09 \\
\hline $\mathrm{SD}_{2}$ & 0.2724 & 0.4518 & 0.4518 \\
\hline $\mathrm{CV} \% 2$ & 24.5 & 41.3 & 41.3 \\
\hline $\mathrm{C}_{\mathrm{A}}$ & 0.8475 & 0.7534 & 0.8824 \\
\hline IFE & 0.1525 & 0.2466 & 0.1176 \\
\hline Remarks* & $\mathrm{NS}$ & NS & NS \\
\hline
\end{tabular}

For Mean $\mathrm{SD}_{1}, \mathrm{CV} \% 1$ and the 2, 2, 2, series, see Table 2; $\mathrm{C}_{\mathrm{A}}$ and IFE, see Table 2. NS = results not significantly different at $r=0.01, n-2=8-2=6(\mathrm{df})$, critical level of 0.834 . 
Table 8. Essential amino acid scores of the red viscera of $T$. swingerianus samples based on requirements of pre-school child (2-5years) [30]

\begin{tabular}{|l|l|l|l|l|l|l|l|}
\hline $\begin{array}{l}\text { Amino } \\
\text { acid }\end{array}$ & Liver & Kidney & Heart & Mean & SD & CV\% & $\chi_{2}$ \\
\hline Val & 1.83 & 1.30 & 1.77 & 1.63 & 0.290 & 17.8 & 0.103 \\
\hline Thr & 1.60 & 0.735 & 0.735 & 0.877 & 0.245 & 28.0 & 0.137 \\
\hline Ile & 1.50 & 1.44 & 1.50 & 1.48 & 0.036 & 2.42 & 0.002 \\
\hline Leu & 1.21 & 1.23 & 0.486 & 0.975 & 0.424 & 43.5 & 0.120 \\
\hline Lys & 1.12 & 1.15 & 0.967 & 1.08 & 0.098 & 9.10 & 0.006 \\
\hline Met+Cys & 1.66 & 2.12 & 2.70 & 2.16 & 0.521 & 24.1 & 0.181 \\
\hline Phe+Tyr & 1.36 & 1.29 & 1.30 & 1.32 & 0.038 & 2.88 & 0.001 \\
\hline His & 1.32 & 1.21 & 1.26 & 1.26 & 0.055 & 4.36 & 0.002 \\
\hline Total & 1.35 & 1.27 & 1.19 & 1.27 & 0.080 & 6.30 & 0.004 \\
\hline
\end{tabular}

$\chi_{2}=$ all chi-square values were insignificantly different at $\mathrm{k}-1=3-1=2(\mathrm{df})$ at $\alpha=0.05$. [Note: critical value $=5.99$.]

Table 9. Statistical analysis of the data from Table 8 concerning the amino acid scores of the samples based on pre-school child (2-5years) requirements [30]

\begin{tabular}{|l|l|l|l|}
\hline Statistics & Liver/Kidney & Kidney/Heart & Liver/Heart \\
\hline$r_{x y}$ & 0.6269 & 0.8621 & 0.8072 \\
\hline$r_{x y 2}$ & 0.3930 & 0.7431 & 0.6516 \\
\hline$R_{x y}$ & 0.9627 & 1.54 & 2.21 \\
\hline Mean $_{1}$ & 1.39 & 1.31 & 1.39 \\
\hline $\mathrm{SD}_{1}$ & 0.2356 & 0.3619 & 0.2356 \\
\hline $\mathrm{CV} \% 1$ & 17.0 & 27.7 & 17.0 \\
\hline $\mathrm{Mean}_{2}$ & 1.31 & 1.32 & 1.32 \\
\hline $\mathrm{SD}_{2}$ & 0.3619 & 0.6446 & 0.6446 \\
\hline $\mathrm{CV} \% 2$ & 27.7 & 48.7 & 48.7 \\
\hline $\mathrm{C}_{\mathrm{A}}$ & 0.7791 & 0.5068 & 0.4391 \\
\hline $\mathrm{IFE}$ & 0.2209 & 0.4932 & 0.5609 \\
\hline Remark & $\mathrm{NS}$ & Significant different & Significant different \\
\hline
\end{tabular}

Mean $\mathrm{SD}_{1}$ and $\mathrm{CV} \%$, all represented the corresponding values in the first member of a pair whereas $2,2,2$, series corresponded to the second pair of the group; NS = result not significantly different at $\mathrm{r}=0.01 ; *$ Results significantly different at $\mathrm{r}=0.01, \mathrm{n}-2(\mathrm{df})=\mathrm{n}-2=9-2=7$ at critical level of 0.798 


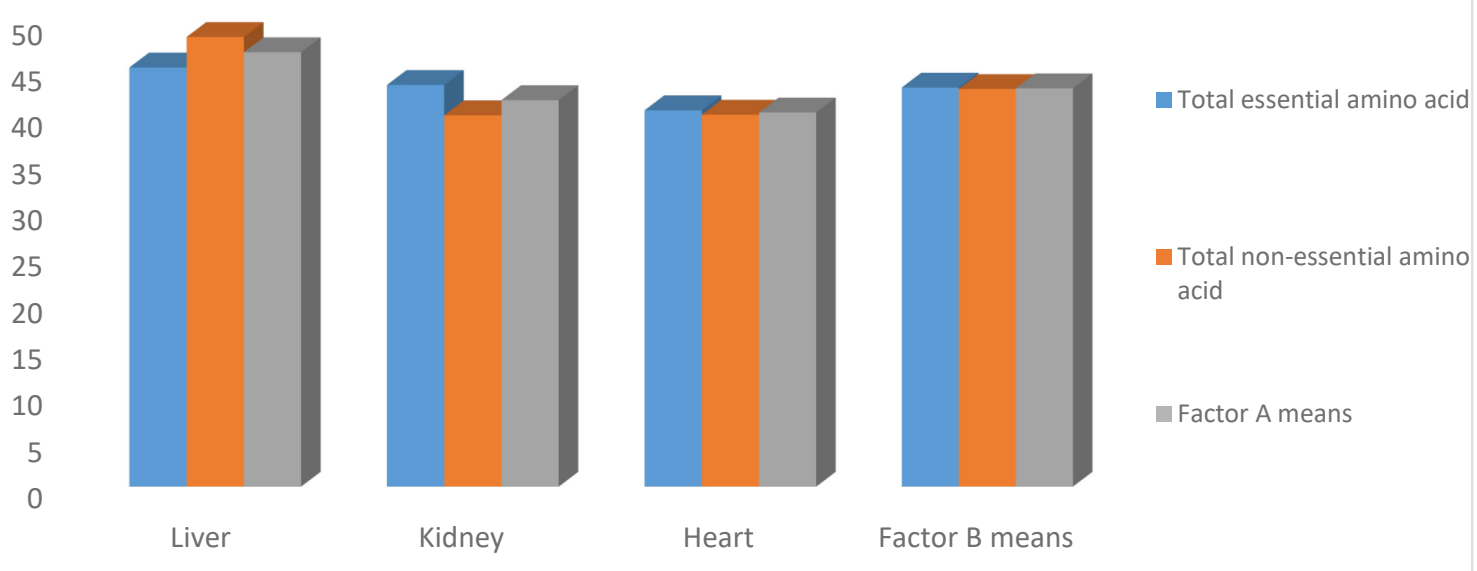

Sample (Factor A)

Fig. 1. Summary of amino acid profiles into Factors A and B

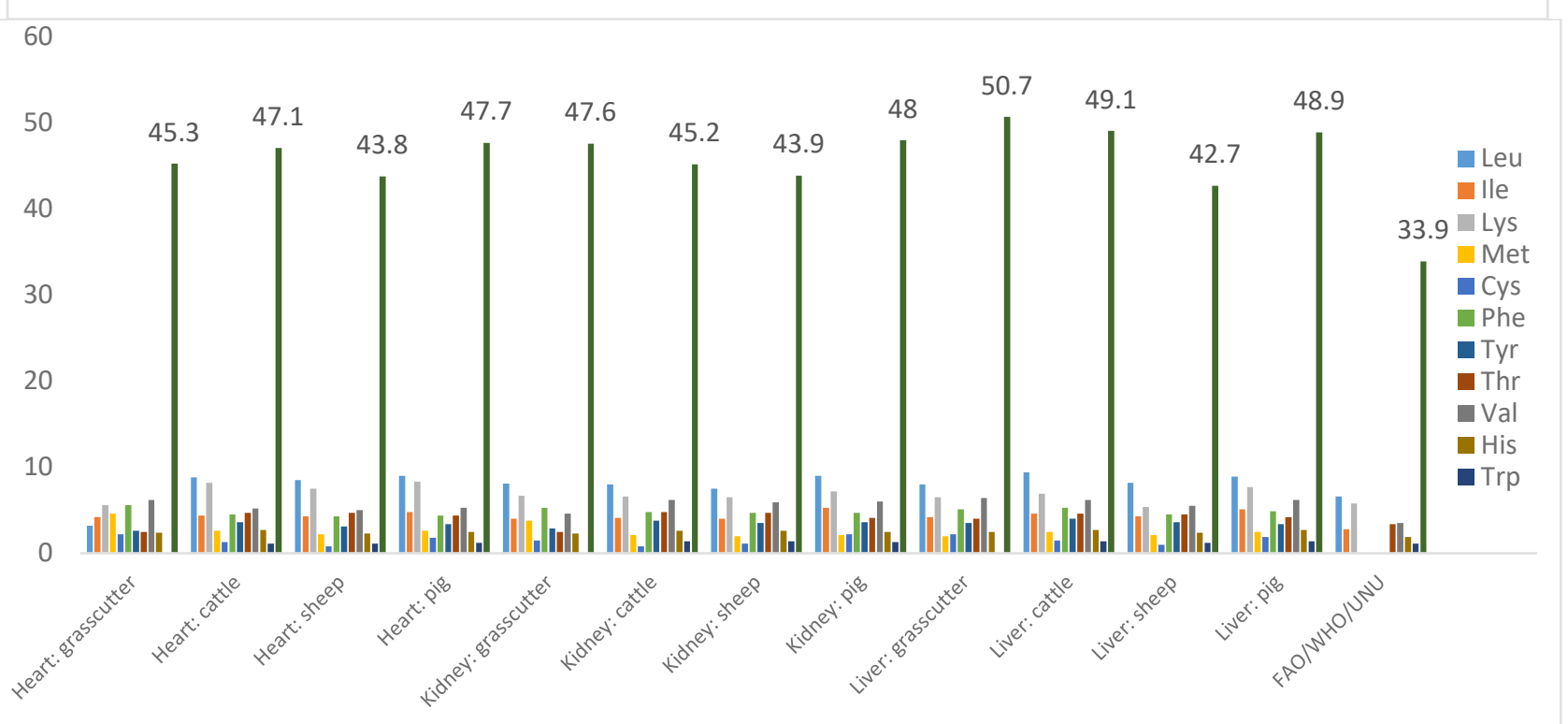

Cystine (Cys) and tyrosine (Tyr) are not essential, but have an economizing effect regarding methionine (Met) and phenylalanine (Phe), respectively.

Fig. 2. Grasscutter red viscera (liver, kidney, heart) compared to the livestock animals (cattle, sheep, pig) viscera and FAO/WHO/UNU standard [30]

\section{References}

[1] PubChem Source Information, The PubChem project. National Center for Biotechnology Information, USA.

[2] Pubchem Wikipedia https://en.m.wikipedia.org/wiki/ PubChem.

[3] FAO, Are grasslands under threat? Brief analysis of FAO statistical data on posture and fodder crops, Food and Agricultural Organization of the United Nations, Rome, 2008.

[4] D. R. Rosevear, The rodents of West Africa, Bristish Museum Publications, London, 1969. 
[5] National Research Council, Microlivestock. Little-known small nutrition. In: Nutrient requirements of laboratory animals, $4^{\text {th }}$ revised edition, National Academy Press Washington DC, 11-79 1991.

[6] M. Vander Merwe, A. Van Zyl, Postnatal growth of the greater cane rat Thryonomys swinderianus in Gauteng, South Africa, Mammalia. 65 (2001) 495-507.

[7] Global Biodiversity Information Facility (GBIF), Thryonomys swingerianus (Temminck, 1827) in GBIF Secretariat (2017), GBIF, Backbone Taxonomy, Checklist dataset https://doi.org/10.15468/39omei accessed via GBIF.org on 2019-07-15

[8] T. S. D. Saanaakyaavuure, Assessment of the consumption trends for grasscutter meat in GaWest municipality and development of a thermal process schedule for canned minced grasscutter meat, M. Phil Thesis, Food Science Degree, College of Basic and Applied Science, University of Ghana, Legon, pp. 1-111, 2015.

[9] A. F. Lynwood, Rodents as a food source. Proceedings of the fourteenth vertebrate pest conference, University of Nebraska-Lincoln 30 (1990) 3-6.

[10] A. E. Assogbadjo, J. T. C. Codjia, B. Sinsin, M. R. M. Ekue, G. A. Mensah, Importance of rodents as a human food source in Benin, Belgium Journal of Zoology. 135 (Supplement) (2005) $11-15$.

[11] K. Abernethy, Bushmeat: Gabon seeks to balance human and wildlife needs, SWARA Magazine, Published by East African Wildlife Society. 34 (1) (2011) 34-39.

[12] S. Blankson-Arthur, P. O. Yeboah, A. Golow, A. O. Tutu, D. Denutsui, Levels of organochlorine pesticide residues in grasscutter (Thryonomys swinderianus) tissues, Published by Maxwell Scientific Organization, Research Journal of Environmental and Earth Sciences. 3(4) (2011) 350-357.

[13] M. N. Opara, B. O. Fagbemi, Occurrence and prevalence of gastrointestinal helminthes in the wild grasscutter (Thryonomys swingerianus Timminck) from Southeast Nigeria, Journal of Life Science. 5(3) (2008) 21-28.

[14] G. H. G. Martin, Bushmeat in Nigeria as a natural resource with environmental implications, Published by the Foundation for Environmental Conservation. 10 (2) (1983).

[15] A. V. Odebode, F. Awe, O. O. Famuyide, O. Adebayo, O. B. Ojo, G. Daniel, Households' consumption patterns of grasscutter (Thryonomys swinderianus) meat within Ibadan Metropolis, Oyo State, Nigeria, Wilolud Journals, Continental Journal of Food Science and Technology. 5(2) (2011) 49-57.

[16] K. A. Etchu, V. N. Nzi, K. J. Ndamukong, B. Obeng, Comparative performance of grasscutter (Thryonomys swinderianus) fed maize and rodent pellets as concentrate supplement under intensive management system in Cameroon, African Journal of Agricultural Research. 7(6) (2012) 883-891.

[17] A. J. Omole, I. O. Ayodeji, O. A. Ashaye, A. K. Tjamiyu, Effect of scalding and flaming methods of processing on physico-chemical and organoleptic properties of grasscutter meat, Published by INSInet Publication. Journal of Applied Sciences Research. 2(2005) 249-252.

[18] E. I. Adeyeye, O. Olaofe, K. E. Ogunjana, Lipid profiles of the skin, muscle and liver of greater cane rat (Thryonomys swinderianus): dietary implications, Elixir Food Sciences. 53 (2012) 11749-11756.

[19] E. I. Adeyeye, R. O. Jegede, Muscle and skin amino acid composition of the greater cane rat (Thryonomys swinderianus), International Journal of Pharma and Bio Sciences. VI (3) (2010) $1-9$. 
[20] O. V. Fornias, Edible byproducts of slaughter animals, FAO Animal, Production and Health Paper 123, FAO of the UN, Rome, pp. 1-23, 1996.

[21] A. Davidson, The Oxford Companion to Food, Oxford University Press, Oxford, 1999.

[22] AOAC Official Methods of Analysis, 18th ed., Association of Official Analytical Chemists Washington, DC, Method 982.30, 2006.

[23] FAO/WHO, Protein quality evaluation, Report of Joint FAO/WHO Expert Consultation, Food and Nutrition Paper 51, FAO, Rome, 1991.

[24] D. Pearson, Chemical Analysis of Foods, $7^{\text {th }}$ ed., Churchill, London, pp. 7-11 1976.

[25] O. Olaofe, E. T. Akintayo, Prediction of isoelectric point of legume and oil seed proteins from their amino acid composition, The J. Technosci. 4 (2000) 49-53.

[26] R. H. Alsmeyer, A. E. Cunningham, M. L. Happich, Equations to predict PER from amino acid analysis, Food Technol. 28 (1974) 24-38.

[27] B. L. Oser, An Integrated Essential Amino Acid Index for Predicting the Biological Value of Proteins, in: A. A. Albanese (ed), Protein and Amino Acid Nutrition, Academic Press, New York, 1959, pp.281-295.

[28] A. A. Paul, D. A. T. Southgate, J. Russel, First Supplement to Mccance and Widdowson's The Composition of Foods; Amino acids, mg per 100g food, fatty acids, g per 100g food, HM Stationary Office, London, 1978.

[29] FAO/WHO, Energy and protein requirements, Technical Report Series No 522, WHO, General, 1973.

[30] FAO/WHO/UNU, Energy and protein requirements, Technical Report Series No 724, WHO, Geneva, 1985.

[31] R. A. Oloyo, Fundamentals of research methodology and applied sciences, ROA Educational Press, Ilaro, Nigeria, 2001.

[32] E. I. Adeyeye, A. J. Adesina, Proximate and mineral compositions, mineral safety index (MSI) of ten organs of African giant pouch rat, International Journal of Pharmacology, Phytochemistry and Ethnomedicine, 9 (2018) 1-9.

[33] E. I. Adeyeye, Proximate, mineral compositions and mineral safety index of eight organs of guinea-fowl (Numidia meleagris), Frontiers in Food Science and Technology, 1(1) (2014) 713.

[34] E. I. Adeyeye, M. O. Aremu, Amino acid composition of two fancy meats (liver and heart) of African giant pouch rat (Cricetomys gambianus), Oriental Journal of Chemistry. 27(4) (2011) 1409-1419.

[35] FAO/WHO, Protein quality evaluation, Report of Joint FAO/WHO Consultation, Bethesda, MD, 4-8 December, 1989, FAO/WHO, Rome, 1990.

[36] H.G. Muller, G. Tobin, Nutrition and food processing, Avi Publishing, Westport, CT, 1980.

[37] E.I. Adeyeye, Amino acid profiles of the flesh of the heterosexual pairs of Neopetrolisthes maculatus, International Letters of Natural Sciences. 61(2017) 23-35.

[38] F. H Steinke, E. E. Prescher, D. T. Hopkins, Nutritional evaluation (PER) of isolated soyabean protein and combination of proteins, J. Food Sci. 45 (1980) 323-327.

[39] FAO, Sorghum and millets in human nutrition, FAO Food Series No 27, FAO/UN, Rome, 1995.

[40] B. Belavady, S G. Srikantia, C. Eopalan, The effect of oral administration of leucine on the metabolism of tryptophan, Biochem. J. 87 (1963) 652-655. 
[41] B. Belavady, P. U. Rao, Leucine and isoleucine content of jowar and its pellagragenicity, Indian Exp. Biol. 17(7) (1979) 659-661.

[42] Y. G. Deosthale, Nutrition dimension of high yielding hybrid crop varieties: Locational and varietal differences in nutritional value, in: FAO Food and Nutrition Series No 27, Sorghum and Millets in Human Nutrition, FAO, 1980, p.82.

[43] E. I. Adeyeye, Amino acid composition of the whole body, flesh and exo- skeleton of female common West African fresh water crab Sudananautes africanus africanus, Pak. J. Nutr. 7 (2008) 748-752.

[44] E.I Adeyeye, The chemical composition of liquid and solid endosperm of ripe coconut, Oriental J. Chem. 20(3) (2004) 471-476.

[45] E. I. Adeyeye, The intercorelation of the amino acid quality between raw, steeped and germinated guinea corn (Sorghum bicolor) grains, Bulletin of the Chemical Society of Ethiopia. 22(1) (2008) 1-7.

[46] E. I. Adeyeye, S. S. Asaolu, A. O. Aluko, Amino acid composition of two masticatory nuts (Cola acuminata and Garcinia kola) and a snack nut (Anacardium occidentale), Int. J. Food Sci Nutr. 58(4) (2007) 241-249.

[47] E. I. Adeyeye, Amino acids and sugar composition of Triticum durum whole meal flour, J. Appl. Environ. Sci. 3(2) (2007) 128-132.

[48] E. I. Adeyeye, Amino acids composition of fermented African locust bean (Parkia biglobosa) seeds. J. Appl. Environ. Sci 2(2) (2006) 154-158.

[49] S. Bingham, Dictionary of Nutrition, Barrie and Jenkins, London, 1977. 